\title{
Peningkatan Kemampuan Literasi Awal Anak Prasekolah melalui Program Stimulasi
}

\author{
Widyaning Hapsari ${ }^{1}$, Lisnawati Ruhaena ${ }^{2}$, E Wiwien Dinar Pratisti ${ }^{3}$ \\ 1,2,3Fakultas Psikologi Universitas Muhammadiyah Surakarta
}

\begin{abstract}
Stimulation program is a treatment by providing literacy packages containing guidebooks literacy activities, media literacy in children and socialization for mothers. The purpose of this study was to test the effectiveness of the stimulation program to improve literacy skills in preschoolers. The proposed hypothesis that stimulation literacy program effective in improving early literacy skills in preschool children. This research method using a quasi-experimental design with non-equivalent control group. Subjects were 30 children aged 3-5 years were divided into an experimental group and a control group. Based on the analysis by the non-parametric statistical test Mann-Whitney U, it was known that there were differences increase early literacy skills in the experimental group and control group. Qualitative analysis showed an increase in the literacy skills by observing changes in the measurement results. Results from this study is important as a new study in finding alternative methods of stimulating preschool children.
\end{abstract}

Keywords: early literacy skills; literacy stimulation

Abstrak. Program stimulasi merupakan perlakuan dengan memberikan paket literasi berisi buku panduan aktivitas dan satu set media literasi pada anak serta sosialisasi untuk ibu. Tujuan penelitian untuk menguji efektivitas program stimulasi dalam meningkatkan kemampuan literasi pada anak prasekolah. Hipotesis yang diajukan yaitu program stimulasi literasi efektif dalam meningkatkan kemampuan literasi awal pada anak prasekolah. Metode yang digunakan yaitu quasi experiment dengan desain non-equivalent control group. Subjek merupakan 30 anak usia 3-5 tahun yang terbagi menjadi kelompok eksperimen dan kontrol. Berdasarkan hasil analisis dengan uji statistik non-parametrik Mann-Whitney U, diketahui bahwa terdapat perbedaan peningkatan kemampuan literasi awal pada kelompok eksperimen dengan kelompok kontrol. Analisis kualitatif menunjukan peningkatan kemampuan literasi dengan mengamati perubahan hasil pengukuran. Hasil penelitian ini penting sebagai kajian baru dalam menemukan alternatif metode stimulasi anak prasekolah.

Kata kunci: kemampuan literasi awal; stimulasi literasi

Hasil survei oleh Organisasi Pengembangan Kerja sama Ekonomi (OECD) menunjukan bahwa budaya baca

\footnotetext{
${ }^{1}$ Korespondensi mengenai artikel ini dapat melalui: hapsariazhar@gmail.com, 2lisnawati.purtojo@ gmail.com, ${ }^{3}$ wiweinpratisti@yahoo.com
}

masyarakat Indonesia menempati posisi terendah dari 52 negara di kawasan Asia Timur. Berdasarkan laporan dari IEA Study of Reading Literacy, kemampuan anak-anak Sekolah Dasar di Indonesia masih sangat rendah, di mana dari 31 
negara yang diteliti, Indonesia menempati urutan 30. Penelitian Farida (2002) menunjukan bahwa kesulitan yang ditemukan pada anak salah satunya adalah kemampuan dasar bahasa di usia dini.

Menurut Snow (dalam Hoff, 2005), anak usia 2 sampai 5 tahun sudah dapat menunjukkan kemampuan literasinya dengan cukup pesat. Pada usia $0-3$ tahun, seharusnya anak mampu mengenali buku melalui sampul, menuliskan huruf, mendengarkan cerita, berpura-pura membaca. Kemudian, anak pada usia 3-4 tahun sudah dapat mengenali tulisan sederhana, mengenal bunyi bahasa yang berbeda, menghubungkan cerita di buku dengan kenyataan, tertarik untuk membaca buku. Pada usia 5 tahun anak seharusnya sudah mampu memprediksian alur cerita dalam buku, mampu menulis nama dan kata dengan dikte.

Peneliti melakukan survei pada $34 \mathrm{ibu}$ di empat Posyandu wilayah Surakarta yang memiliki anak dengan rentang usia 2-5 tahun. Posyandu tersebut yaitu Posyandu Abadi Kelurahan Gonilan, Posyandu Cempaka Kelurahan Mendungan, Posyandu Nusa Indah kelurahan Pabelan, dan Posyandu Melati Kelurahan Karangasem. Survei dilakukan dengan memberikan angket pada ibu yang berisi tentang pengalaman dan perkembangan literasi yang telah didapatkan anak. Hasil survei menunjukan bahwa sebagian besar anak belum menunjukan perkembangan kemampuan literasi sesuai dengan yang diharapkan. Apabila hal tersebut dibiarkan, maka dapat menyebabkan anak kesulitan beradaptasi dengan kegiatan pembelajaran di sekolah formal dan juga menyebabkan guru kesulitan dalam mengembangkan kemampuan lain. Oleh karenanya sangat tepat kiranya jika anak diberikan rangsangan yang lebih terarah dari orang tuanya.

Selain stimulasi, faktor lain yang menyebabkan kurangnya penguasaan kemampuan baca tulis di usia dini adalah metode pembelajaran yang kurang memperhatikan karakteristik anak. Proses pembelajaran pada anak masih banyak yang menggunakan metode konvensional, yaitu orang tua atau guru mengajarkan anak untuk menghafalkan nama alfabet secara berulang dengan media papan tulis dan menirukan cara guru mengucapkannya (Ruhaena, 2013). Oleh karenanya, hal ini harus menjadi perhatian oleh semua pihak, khususnya orang tua agar sedini mungkin mengenalkan kegiatan baca tulis pada anak dengan metode yang menyenangkan.

Pengalaman literasi anak pada usia prasekolah diyakini akan membentuk fondasi yang kuat pada perkembangan membacaya (Levy, Gong \& Hessel, 2005). Pengetahuan, keterampilan, dan sikap anak prasekolah yang menjadi dasar membaca dan menulis disebut dengan kemampuan literasi awal (Whitehurst \& Lonigan, 2001).

Pengajaran pada anak tentunya harus menyenangkan, karena pembelajaran yang tidak menggunakan media atau metode bermain kurang dapat mengoptimalkan fungsi psikis, fisik dan sensoris anak yang tengah berkembang pesat. Anak membutuhkan kesempatan untuk bereksplorasi, bergerak, serta memenuhi kebutuhan utamanya untuk bermain. Menurut Vygotsky (1978), anak akan secara aktif menyusun pengetahuan dan memberi fokus pada bagaimana pentingnya interaksi sosial budaya terhadap perkembangan kognitif mereka. Dengan demikian, perkembangan kognitif anak dipengaruhi oleh pola interaksi dengan orang-orang terdekat anak, yaitu bagai- 
mana orang tua memberikan stimulasi kemampuan literasi pada anak. Bagi anak, rumah adalah sekolah pertama, dengan orang tua sebagai guru dan membaca adalah pelajaran pertamanya. Maka apabila distimulasi sejak dini anak akan mampu menguasai kemampuan literasi selanjutnya dengan lebih mudah. Oleh sebab itu, diperlukan suatu kegiatan terstruktur dalam suatu program stimulasi literasi pada anak di rumah secara konsisten, terarah, dan tepat.

Berdasarkan pemaparan di atas, dapat diketahui bahwa dalam memberikan stimulasi pada anak harus sesuai dengan karakteristik anak yang berorientasi pada kegiatan menyenangkan. Metode dan media yang digunakan merupakan faktor penting dalam memenuhi kegiatan literasi yang menyenangkan. Oleh karena itu, penelitian ini mencoba untuk menerapkan suatu program stimulasi bagi anak di rumah dengan metode dan media yang sesuai karakteristik anak. Program yang dimaksudkan berupa pemberian paket literasi terdiri dari panduan aktivitas literasi dan media literasi, serta sosialisasi bagi orang tua.

Penelitian ini bertujuan untuk menguji efektivitas program stimulasi dalam meningkatkan kemampuan literasi awal pada anak prasekolah. Hipotesis yang diajukan adalah program stimulasi efektif dalam meningkatkan kemampuan literasi awal pada anak prasekolah.

\section{Metode}

Variabel yang diteliti pada penelitian ini yaitu program stimulasi sebagai variabel bebas atau tritmen, serta kemampuan literasi awal sebagai variabel terikat. Program stimulasi merupakan dukungan instrumental dengan memberikan paket literasi untuk anak yang disertai dengan sosialisasi bagi ibu. Paket literasi berisi buku panduan aktivitas dan media literasi diantaranya buku cerita anak, boneka, permainan edukatif, dan alat tulis. Sedangkan sosialisasi merupakan panduan verbal bagi ibu agar dapat memfasilitasi anak selama program berlangsung. Program berlangsung selama satu bulan dengan bantuan ibu sebagai subjek sekunder untuk mencatat aktivitas yang dilakukan anak selama masa tersebut.

Kemampuan literasi awal adalah pengetahuan, sikap dan keterampilan seorang anak usia dini yang berkaitan dengan membaca dan menulis sebelum menguasai kemampuan formal pada usia sekolah. Kemampuan tersebut diukur menggunakan alat ukur kemampuan literasi awal dari Ruhaena (2013) yang berisi komponen-komponen literasi awal, yaitu minat membaca, kemampuan bahasa, kesadaran fonologis, kemampuan membaca, dan kemampuan menulis. Semakin tinggi skor yang diperoleh subjek, maka semakin tinggi pula kemampuan literasinya. Semakin rendah skor yang didapatkan, menunjukan semakin rendah pula kemampuan literasi subjek.

Penelitian ini menggunakan metode quasi experiment yang memiliki perlakuan, pengukuran dampak, dan mempunyai kelompok kontrol dengan rancangan nonequivalent control group design. Perlakuan yang diberikan pada kelompok eksperimen berupa pemberian paket literasi. Sedangkan kelompok kontrol tidak diberikan perlakuan apapun. Jumlah keseluruhan subjek dalam penelitian ini adalah 30 anak berusia 3-5 tahun yang terbagi menjadi kelompok eksperimen dan kontrol

Analisis data pada penelitian ini menggunakan strategi embedded konruen yang menerapkan satu tahap pengum- 
pulan data kuantitatif dan kualitatif dalam satu waktu. Metode sekunder yang kurang diprioritaskan ditambahkan pada metode yang lebih dominan, artinya metode sekunder berfungsi untuk menjabarkan rumusan masalah berbeda dari metode primer. Analisis kuantitatif dilakukan dengan mengolah skor skala kemampuan literasi awal menggunakan Mann-Whitney $U$ Test yang merupakan pengukuran statistik non parametrik. Perhitungan selengkapnya dilakukan dengan bantuan komputer program statistik SPSS for MS Windows version 16. Skor subjek diperoleh dari pengukuran pretest, postest dan follow up. Berdasarkan skor-skor tersebut, didapatkan selisih skor (gained score) antara postest dengan pretest serta follow up dengan posttest. Selisih skor tersebutlah yang kemudian dianalisis menggunakan SPSS untuk mengetahui perbedaaanya antar kelompok subjek.

Data kualitatif diperoleh melalui pencermatan terhadap perubahan skor kemampuan literasi awal pada pretest dan posttest hingga follow up. Pencermatan juga didukung dengan analisis terhadap catatan aktivitas anak yang ditulis oleh ibu sebagai tutor anak. Data dari pencatatan ini dapat digunakan untuk menjelaskan perubahan skor yang terjadi sebelum dan setelah treatment pada subjek.

\section{Hasil}

\section{Data deskriptif}

Hasil pengukuran dalam penelitian ini terdiri dari skor kemampuan literasi awal. Data deskriptif perolehan skor dapat dilihat pada Tabel 1. Sedangkan perubahan skor dapat dilihat melalui grafik di Gambar 1.

\section{Analisis kuantitatif}

Skor kemampuan literasi awal dianalisis menggunakan Mann-Whitney $U$ dikarenakan sampel dalam penelitian ini berukuran kecil. Mann-Whitney $U$ Test bertujuan untuk mengetahui ada atau tidak perbedaan peningkatan kemampuan literasi awal pada kedua kelompok. Pengujian tersebut dilakukan dengan membandingkan perubahan skor yang terjadi pada masing-masing kelompok. Sedangkan hasil uji hipotesis dapat dilihat pada Tabel 2.

Tabel 1

Data deskriptif skor kemampuan literasi awal

\begin{tabular}{cclccccc}
\hline Kelompok & $\mathbf{N}$ & Tahap & Range & Minimum & Maximum & Mean & SD \\
\hline eksperimen & 15 & Pretest & 28 & 3 & 31 & 14.27 & 7.759 \\
& & Postest & 23 & 13 & 36 & 22.07 & 6.307 \\
& & Follow up & 24 & 16 & 40 & 24.60 & 7.434 \\
\multirow{3}{*}{ kontrol } & 15 & Pretest & 29 & 7 & 36 & 17.07 & 7.968 \\
& & Postest & 30 & 6 & 36 & 16.60 & 7.980 \\
& & Follow up & 29 & 6 & 35 & 14.40 & 7.109 \\
\hline
\end{tabular}




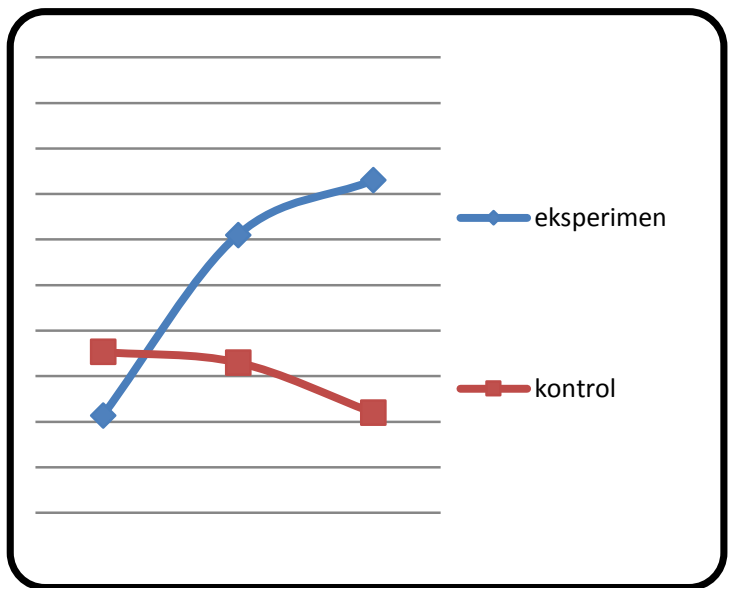

Gambar 1. Grafik perubahan skor rerata kemampuan literasi

Tabel 2.

Hasil analisis statistik Mann-Whitney U Test

\begin{tabular}{lc}
\hline & $\begin{array}{c}\text { kemampuan } \\
\text { literasi }\end{array}$ \\
\hline $\mathrm{Z}$ & -4.679 \\
Asymp. Sig. (2-tailed) & .000 \\
Exact Sig. [2*(1-tailed Sig.)] & $.000^{\mathrm{a}}$ \\
\hline
\end{tabular}

Tabel 2 menunjukan adanya perbedaan peningkatan kemampuan literasi awal pada kelompok eksperimen dan kelompok kontrol $(p=0,000 ; \quad p<0,05)$. Perbedaan tersebut juga ditunjukan melalui perbedaan mean pada masingmasing kelompok. Kemampuan literasi awal pada kelompok eksperimen memiliki mean lebih tinggi dibandingkan kelompok kontrol. Hal tersebut menunjukan bahwa kelompok yang diberikan paket literasi mengalami peningkatan kemampuan literasi lebih baik dibandingkan kelompok yang tidak mendapat perlakuan.

\section{Analisis kualitatif}

Analisis kualitatif dilakukan dengan mengamati perubahan skor kemampuan literasi awal serta buku catatan aktivitas. Aspek kemampuan literasi awal yang mengalami peningkatan pada masingmasing anak berbeda. Minat membaca ditunjukan dengan respon anak yang menceritakan isi buku yang dilihatnya saat menerima buku bacaan. Peningkatan aspek bahasa ditunjukkan dengan kemampuan anak dalam mengkomunikasikan jawaban di setiap pertanyaan, khususnya persoalan dalam aspek bahasa. Kemudian, kesadaran fonologis ditunjukan dengan kemampuan anak dalam mengeja suku kata sederhana. Saat pengukuran awal subjek hanya mengulang kata yang disebutkan, namun beberapa subjek mampu menyebutkannya dengan mengeja suku kata ketika pengukuran kedua. Kemampuan membaca subjek ditunjukan dengan pemahamannya dalam aturan membaca, terkait arah baca dan mengenali sampul buku. Akan tetapi untuk membaca kata sederhana dan menyebutkan alfabet dengan urut masih banyak anak yang belum menguasainya. Sedangkan dalam aspek menulis, peningkatan subjek ditunjukan dengan kemampuannya dalam menarik garis serta menebalkan kata.

Berdasarkan buku catatan aktivitas, dapat diketahui bahwa aktivitas yang gemar dilakukan anak bersama orang tua di rumah adalah bemain. Plastisin yang menjadi salah satu media dalam paket menjadi permainan yang cukup digemari subjek. Beberapa subjek yang mengalami peningkatan signifikan kemampuan literasi awal, mendapatkan dukungan baik dari keluarga khususnya ibu. Dukungan tersebut berupa pendampingan dan motivasi agar subjek secara konsisten tertarik untuk melakukan aktivitas literasi di rumah. Oleh karena itu, orang tua terlebih dahulu perlu menyadari tentang pentingnya memberikan stimulasi diri dan memiliki pemahaman tentang cara-cara yang efektif untuk melakukannya. 


\section{Diskusi}

Kemampuan literasi awal diketahui mengalami peningkatan pada semua subjek selama berlangsungnya program. Aspek-aspek kemampuan literasi meningkat secara merata pada semua subjek. Meningkatnya kemampuan literasi sangat dipengaruhi oleh pengalaman yang telah didapatkan subjek. Pengalaman tersebut telah didapatkan subjek selama proses penelitian ini yaitu diberikannya mediamedia literasi yang bertujuan untuk meningkatkan berbagai aspek kemampuan literasi.

Pada analisis kualitatif, dapat dikatakan bahwa kemampuan literasi awal dapat ditingkatkan dengan memberikan stimulasi berupa media literasi yang menarik bagi anak. Selain media yang menarik, peran lingkungan keluarga sangatlah penting. Hal tersebut dikarenakan anak membutuhkan adanya bimbingan atau pendampingan dari orang tua sebagai tutor bagi anak. Ibu yang mampu memberikan motivasi pada anak haruslah memiliki kesadaran tentang pentingnya memberikan stimulasi pada anak sedini mungkin.

Hasil penelitian ini sesuai dengan konsep teori Vygotsky (1978) yang menekankan hakekat sosiokultural dalam proses belajar. Kecerdasan pada anak tumbuh bersama interaksinya dengan lingkungan. Pengaruh dari lingkungan tersebut berupa pemberian rangsangan yang tepat yaitu stimulasi literasi. Vygotsky mengemukakan tentang konsep Zona Proximal Development (ZPD), scaffolding, dan pembelajaran kooperatif.

ZPD merupakan proses seorang anak mempelajari hal baru yang masih berada dalam area potensial kemampuan anak. Pada penelitian ini, pemberian stimulasi dimaksudkan untuk memberi pengalaman literasi baru pada subjek. Pengalaman literasi tersebut dilakukan dengan memberikan rangsangan melalui media-media literasi yang dapat menumbuhkan minat subjek untuk melakukan aktivitas baru dalam literasi. Berdasarkan hasil penelitian ini, diketahui bahwa pemberian pengalaman baru dalam bentuk stimulasi telah dapat meningkatkan kemampuan literasi awal pada subjek.

Scaffolding adalah pemberian bantuan atau bimbingan yang diberikan orang dewasa pada anak di tahap awal pembelajaran hingga anak dapat lebih mandiri dalam memecahkan berbagai persoalan. Sangat diperlukan peran Ibu sebagai sosok terdekat, untuk membantu subjek menggunakan paket literasi. Peran yang diberikan ibu subjek dalam penelitian ini adalah pendampingan saat subjek ingin melakukan aktivitas literasi. Misalnya membacakan buku cerita, mengenalkan huruf-huruf, mengajarkan cara-cara menulis. Diketahui dari hasil penelitian bahwa peran yang diberikan ibu dalam membimbing dan memotivasi subjek, mampu meningkatkan kemampuan literasi awal pada subjek.

Pada penelitian ini salah satu stimulasi yang diberikan dalam program adalah memberikan buku cerita yang menarik bagi subjek. Peningkatan aspekaspek kemampuan literasi dapat terjadi dengan membacakan buku cerita. Hal tersebut sesuai dengan hasil penelitian yang dilakukan oleh Aram, Most \& Mayafit (2006), Stephenson, Parilla, Georgiou, \& Kirby (2008), Raikes, BrooksGunn, Raikes, Pan, \& Tamis La-Monde (2006) yang menyebutkan bahwa rangsangan pada anak dalam bentuk membacakan buku cerita berkorelasi dengan kesadaran fonologis, pengetahuan umum, dan bahasa reseptif. Kemudian, penelitian yang dilakukan oleh Senechal 
(2008) juga menyebutkan bahwa shared book reading yang dilakukan oleh anak dan orang tua mampu meningkatkan kosakata ekspresif dan pengetahuan morfologi. Hal tersebut juga dibuktikan pada penelitian ini dimana perkembangan bahasa dan kesadaran fonologis subjek menunjukan kemajuan lebih baik setelah diberikan buku cerita anak dan menggunakannya bersama orang tua.

Menurut Justice \& Kaderavek (2002), anak-anak mengumpulkan pengetahuannya akan pemahaman bahasa dimulai sejak kelahiran hingga usia 6 tahun. Pengetahuan tersebut tidak didapatkan melalui pengajaran, namun melalui perila$\mathrm{ku}$ sederhana dengan cara berpartisipasi pada aktivitas literasi. Aktivitas literasi mendukung pencapaian kemampuan literasi anak (Burgess, 2002; Lynch, 2008). Sejalan dengan hasil dalam penelitian ini, subjek yang mendapatkan perlakuan program stimulasi menunjukan kemampuan literasi lebih baik daripada subjek yang tidak diberikan program.

Namun demikian, berbeda dari penelitian sebelumnya yang memberikan perlakuan melalui pelatihan pada ibu atau anak, penelitian ini mencoba memberikan stimulasi berupa paket literasi yang dapat digunakan oleh anak dan orang tuanya di rumah. Selain itu, beberapa penelitian sebelumnya hanya menggunakan satu jenis metode untuk meningkatkan salah satu aspek literasi. Sementara itu, salah satu isi dalam paket literasi dari penelitian ini adalah panduan aktivitas literasi yang menggunakan multimetode untuk meningkatkan kemampuan literasi awal meliputi minat baca, kemampuan berbahasa, kesadaran fonologis, keterampilan membaca dan keterampilan menulis.

Stimulasi yang diberikan dalam bentuk program selama satu bulan pada subjek mampu membantu subjek dalam meningkatkan kemampuan literasinya. Hal tersebut diketahui dari perolehan skor subjek, wawancara dengan ibu, dan pengamatan pada perubahan perilaku subjek. Berdasarkan wawancara, diketahui bahwa ibu merasa terbantu dengan diberikannya paket literasi yang sangat bermanfaat dalam merangsang kemampuan literasi subjek.

Kesadaran dan pemahaman orang tua terhadap pentingnya stimulasi literasi menjadi dasar dalam mengembangkan kemampuan literasi anak. Pemahaman orang tua berkaitan dengan cara atau teknik yang tepat digunakan dalam melakukan aktivitas literasi dengan anak. Kebanyakan orang tua dalam penelitian ini kurang mampu mengembangkan kreativitas untuk membuat variasi aktivitas pada anak, sehingga anak mengalami kebosanan setelah program berakhir. Hal tersebut menunjukan bahwa di Indonesia, orang tua cenderung pasif dalam mendorong anak agar aktif dalam aktivitas literasi.

\section{Kesimpulan}

Hasil penelitian menunjukan bahwa program stimulasi efektif dalam meningkatkan kemampuan literasi. Temuan selanjutnya adalah kesadaran dan pemahaman orang tua terhadap pentingnya stimulasi literasi menjadi dasar dalam mengembangkan kemampuan literasi anak.

Hal tersebut membuktikan bahwa dengan memberikan rangsangan berupa media literasi yang tepat bagi anak dapat menumbuhkan minat anak untuk melakukan kegiatan literasi sehingga meningkatkan kemampuan literasinya. 
Saran

Pentingnya jenis media dan metode literasi yang dipilih menjadi tantangan sendiri bagi orang tua untuk selalu berkreasi agar anak dengan senang hati melakukan aktivitas literasi. Oleh karenanya diharapkan orang tua aktif dalam mengembangkan pengetahuan serta keterampilannya untuk membimbing anak dalam aktivitas literasi.

\section{Kepustakaan}

Aram, D., Most, T., Mayafit, H. (2006). Contribution of mother-child storybook telling and joint writing to literacy development in kindergarteners with hearing loss. Language, Speech, and Hearing Services in School, 37(1), 209-223.

Burgess, S. R, Hecht A. S., \& Lonigan, C. J. (2002). Relation of the home literacy environtment (HLE) to the development of reading-related abilities: a one-year longitudinal study. Reading Research Quarterly, 37(4), 408-426.

Farida, E. (2002). Kemampuan bahasa Taman Kanak-Kanak. Jurnal Psikologi Pendidikan. Bandung : FIP UPI

Hoff, E. (2005). Language development. Belmont, CA : Wodswooth Learning.

Justice L. M., \& Kaderavek, J. (2002). Using shared storybook reading to promote emergent literacy, Teaching Exceptional Children, 34(4), 8-13

Lynch, J., Anderson, J., Anderson A., \& Shapiro J. (2006). Parent's beliefs about young children's literacy development and parent's literacy behaviors. Reading Psychology, 27, 1-20. doi: 10. 1080/02702710500468708.
Levy, B. A., Gong, Z., \& Hessel, S. (2005). Understanding print: Early reading development and the contribution of home literations of home literacy experiences. Experimental Child Psycology, 93, 63-93.

Raikes, H., Luze, G., Brooks-Gunn, J., Raikes, H. A., Pan, B. A., \& TamisLeMonda, C.S., (2006). Mother Child book reading in low income families: Correlates and outcomes during the first three years of life. Child Development, 77(4), 924-953.

Ruhaena, L. (2013). Proses pencapaian kemampuan literasi dasar anak prasekolah dan dukungan faktor-faktor dalam keluarga. Universitas Muhammadiyah Surakarta

Senechal, M., \& Young, L. (2008). The effect of family literacy intervention on children's acquisition of reading from kindergarten to grade 3: A meta analytic review. Review of Educational Research, 78(4), 880-907

Stephenson, K. A., Parilla. R. K., Georgiou, G. K., \& Kirby, J. R. (2008) Effects of home literacy, parent's beliefs and children's task-focused behaviour on emergent literacy and word reading skills. Scientific Studies of Reading, 12(1), 24-50. doi: 10.1080/10888430701746864

Vygotsky, L. S. (1978). Mind in society. Cambridge, MA: Harvard University

Press.

Whitehurst, G. J. \& Lonigan, C. J. (2001). Emergent literacy: Development from prereaders to reader. Dalam S. B. Neuman $\mathcal{E}$ Dickinson (eds), Handbook of early literacy research ( $p p$. 11-28). New York: Guilford Press 